\title{
ANALYSIS ON EFFECT OF SEPARATION AND PURIFICATION OF GLYCOPROTEIN EXTRACTED FROM CAMELLIA SEEDS AND ITS FUNCTIONAL ACTIVITY AS BASIS FOR THE ECONOMIC DEVELOPMENT OF CAMELLAA OLEIEERA
} INDUSTRY

\author{
Aiguo FENG*, Gang LIU ${ }^{* * 1}$ \\ ${ }^{*}$ College of Food Science and Technology, Hainan University, Haikou \\ 570228, China \\ ${ }^{* *}$ School of Hospitality and Tourism Management, Hainan University, \\ Haikou, 570228, China
}

\begin{abstract}
Taking Camellia oleiferaseeds as raw materials, this study explored extraction and purification of glycoprotein separated from Camellia seedsas well as its antitumor activity, aiming to provide a theoretical basis for the economic development of Camellia oleiferaindustry. Key impact factors ofCamellia seed glycoproteinwere extracted using buffer solution method and water extraction methodand a regression model was set up. Methyl thiazolyl tetrazolium was used to evaluatethe in vitroantitumor activity of glycoprotein extracted from Camellia seeds and Differential Scanning Calorimetry (DSC) was used to measure its denaturation enthalpy value. Results indicated that protein and sugar yields were $8.96 \%$ and $17.05 \%$ respectively under optimal conditions when water extraction method was used. Crude glycoprotein extracted from Camellia oleiferahad a certain inhibitory effect on human hepatoma cell HepG2, gastric cancer cell MGC-803 and breast cancer cell MCF-7 and crude glycoprotein extracted from Camellia oleiferaby water-extraction and alcohol-precipitation method had a strong antitumor effect. Crude
\end{abstract}

${ }^{1}$ Correspondingauthor. Complete adress: School of Hospitality and Tourism Management, Hainan University, Haikou, 570228, China. E-mail: liugang0286@ sina.com 
glycoprotein obtained in the two different ways was capable of scavenging $\mathrm{DPPH}, \bullet \mathrm{OH}$ and $\mathrm{O}_{2} \mathrm{~g}$ - free radicals and also showed good reducing capacity. DSC measurement results revealed that specific rotation of COGP2a $[\alpha]_{n}^{20}$ was - 32.5. Antitumor experiment in vitro showed that glycoprotein extracted from Camellia seeds in the two different ways had a certain inhibitory effect on HepG2, MGC-803 and MCF-7, which has important theoretical and realistic significances to promoting utilization value of camellia resources, strengthening Camellia oleifera's comprehensive development and utilization of high added value as well as enriching types and functions of active glycoprotein.

Keywords: Camellia oleifera; glycoprotein; tumor resistance; cell apoptosis; oxidation resistance

\section{INTRODUCTION}

Camellia oleifera, a kind of high effective economic forest, has high and stable yield in a small area compared with grain and oil crops (Dos Santoset al.,2014). In China, Camellia oleiferaindustry has a good prospect for development and broad market space. Camellia oleiferamarket is not monopolized and Camellia oleiferaenterprises are small-scaled due to low concentration degree, thus the market competition is intense. There are a variety of Camellia oleiferaproducts. At present, blend oil is a major profit source while pure camellia oil has very low profits (Dawson et al.,2014). Blend oil is mostly mixed with soybean oil and palm oil as there is no clear national standard. Enterprises compete on price, which is easy to form a vicious competition situation. Due to large market demand, Camellia oleiferaoutput of large-scale enterprises grows quickly.

Main glycoprotein preparation methods include direct extraction from living bodies in the nature, artificial synthesis and biological carrier recombination, etc(Gavrovic-Jankulovicet al.,2008). Aqua pure extraction (Liet al.,2012), buffer solution extraction (Bariket al.,2013) and ethanol extraction (Jinet al.,2011) are the most commonly used methods for the extraction of glycoprotein. Camellia oleiferais easy to be dissolved in ethanol solution, but not soluble in cold water as a result of the existence of $\operatorname{saponin}(\mathrm{Wu}$ et al.,2011). Currently, methods for evaluating in vitro antitumor activity of samples include methyl thiazolyl tetrazolium (MTT) reduction method, 3, 3 '(1 - (benzene ammonia acyl) - 3, 4 - four azole nitrogen) - 2 (4 - methoxy - 6 
- nitro benzene sulfonic acid sodium (XTT) reduction method, CCK-8 method, sulfonyl rhodamine B (SRB) staining method, 51Cr release test, colony formation (Kang et al.,2013, Sousa et al.,2010, Guoet al.,2015). MTT has been widely applied in large-scale in-vitro screening of antitumor drugs as well as cytotoxicity test because of its high cost performance and sensitivity. The testing principle is that MTT is a kind of dyestuff which can accept hydrogen (Steiner et al.,2014).

Detection of in vitro antioxidant activity of natural products mainly focuses on inhibitory effect on lipid peroxidation of substrates, scavenging effect on certain free radicals and reducing capacity on substrates (Zhao et al.,2012). Measurement of peroxide value (PV), ferric thiocyanate (FTC) method, Kreis test, thiobarbituric acid (TBA), carbonyl value (2, 4 - dinitrobenzene hydrazine method) and anisidine value (Islam et al.,2013) are used to detect anti-lipid peroxidation. The measurement of reducing capacity of samples can also be used to evaluate oxidation resistance. In addition, total oxidation resistance measurement is also a commonly used method currently(Šebrlováet al.,2015).

\section{MATERIALS AND METHODS}

\section{Experimentalmaterials and reagents}

Glycoprotein extracted from Camellia seeds, human hepatoma cell HepG2, gastric cancer cell MGC-803, breast cancer cell MCF-7, bovine serum albumin (BSA), DPPH, dimethylsulfoxide (DMSO), absolute ethyl alcohol, trihydroxymethylaminomethane (Tris), Coomassie brilliant blue (CBB), phenol, concentrated sulfuric acid, $\mathrm{H} 2 \mathrm{O} 2$, phenanthroline, ferrous sulfate, potassium ferricyanide, acrylamide, ferric trichloride, trichloroacetic acid (TDA), pyrogallol, ammonium sulfate, paclitaxel injection, MTT, RPMI-1640, dulbecco's modified eagle medium (DMEM), glycine, fetal calf serum (FCS) and 96 - well cell culture plate were used in this experiment.

\section{Experimental facilities}

ALPHA1-2 freezer dryer, UVmini-1240 ultraviolet spectrophotometer, pp-15pH meter, BS210S electronic scales, SW-CJ-1FD clean bench, XD-101CO2 incubator, EL-x800 enzyme-labeled detector, DBS-100-LCD computer automatic fraction collector, WXG-4 disc specific optical rotation and IX51 biological inverted microscope were applied in this experiment. 


\section{Determination of content and yields of sugar and protein}

(1) Determination of protein content

CBB was applied to determine the protein content in glycoprotein. Standard protein liquid $(0.1 \mathrm{mg} / \mathrm{mL})$ was prepared with BSA, 0, 0.2, 0.4, 0.6, 0.8, 1.0 $\mathrm{mL}$ of which was taken respectively and complemented to $1 \mathrm{~mL}$ with distilled water. After that, $5 \mathrm{~mL}$ of CBB G-250 reagent was added and mixed, and then it was put aside for $5 \mathrm{~min}$. Its absorbance was then measured at the wavelength of $595 \mathrm{~nm}$ and a standard curve was drawn. An equation $\mathrm{y}=$ $0.0071 \mathrm{x}+0.0111, \mathrm{R} 2=0.9991$ was obtained, in which $\mathrm{y}$ refers to protein concentration $(\mu \mathrm{g} / \mathrm{mL})$ and $\mathrm{x}$ refers to absorbance under the concentration. The diluted liquid sample was determined in the same way and its concentration was figured out by the standard curve.

(2) Determination of polysaccharide content

This experiment used phenol-sulphuric acid method to determine polysaccharide content in glycoprotein. Glucose was made into standard glucose solution $(0.1 \mathrm{mg} / \mathrm{L}), 0,0.2,0.4,0.6,0.8,1.0,1.2$ and $1.4 \mathrm{~mL}$ of which was accurately taken and complemented to $2.0 \mathrm{~mL}$ with distilled water. Phenol solution $(1.0 \mathrm{~mL})$ with the mass fraction of $6 \%$ was added and shaken up, and then $5 \mathrm{~mL}$ of concentrated sulfuric acid was added and placed at room temperature for half an hour. Afterwards, its absorbance was measured at the wavelength of $490 \mathrm{~nm}$ and a standard curve was drawn. An equation $\mathrm{y}=0.0129 \mathrm{x}+0.0088, \mathrm{R} 2=0.9994$ was obtained, in which y refers to sugar concentration $(\mu \mathrm{g} / \mathrm{mL})$ and $\mathrm{x}$ refers to the absorbance under the concentration. The diluted liquid sample was determined in the same way and its concentration was figured out by the standard curve.

(3) Calculation of protein and sugar yields

Protein and sugar yields were calculated according to the following formula:

$$
r=\frac{C V N 10^{-6}}{m} \times 100(1-1)
$$

where CVN stands for the quality of protein (polysaccharide) and $\mathrm{m}$ stands for the quality ofraw Camellia seeds.

\section{Determination ofin vitro antitumor activity of crude glycoprotein extracted from Camellia seeds}

MTT was used to determine antitumor activity in vitro of crude glycoprotein extracted from Camellia seeds (Fragaet al.,2011, Kreulet al.,2012). Human 
hepatoma cell HepG2, gastric cancer cell MGC-803 and breast cancer cell MCF-7 in the logarithmic phase were taken and made into cell suspensions $(5 \times 104 / \mathrm{mL})$. Then, $100 \mu \mathrm{L}$ of each cell suspension was added into each well of a 96-well plate for cell culture and the plate was then put into an incubator which contained $5 \% \mathrm{CO} 2$ for $24-\mathrm{h}$ culture $\left(37^{\circ} \mathrm{C}\right)$. After the culture medium was abandoned and cells were washed with phosphate buffered saline (PBS) twice, samples were diluted into differently concentrated medium $(0.78,3.12$, $12.50,50$ and $200 \mu \mathrm{g} / \mathrm{mL}$ ) with complete medium and each well was added with $200 \mu \mathrm{L}$ medium. Negative control group was added with the same amount of the sample diluents and positive control group was added with 10 $\mu \mathrm{g} / \mathrm{mL}$ of paclitaxel, with 6 replica wells in each group. The 96 -well plate was then put into an incubator which contained $5 \% \mathrm{CO} 2$ for culture $\left(37^{\circ} \mathrm{C}\right)$. Seventy-two hours later, each well was added with $20 \mu \mathrm{L}$ of MTT $(5 \mathrm{mg} / \mathrm{mL})$ and then incubated for $4 \mathrm{~h}$, and then the culture medium was abandoned. Each well was added with $150 \mu \mathrm{L}$ of DMSO solution and mixed evenly for ten minutes, and each well's optical density (OD) value was measured at 490 $\mathrm{nm}$. Inhibition ratio of differently concentrated samples to each tumor cell was calculated and half maximal inhibitory concentration (IC50) was worked out using SPSS17.0 software.

Changes of morphology of tumor cells which had the highest inhibition ratio were observed under an inverted optical microscope and images were taken $(200 \times)$.

\section{Determination of antitumor activity in vitro of crude glycoprotein extracted from Camellia seeds}

(1) DPPH scavenging capacity

Referring to methods mentioned in literatures (Zhao et al.,2011, Metwalyet al.,2013), crude glycoprotein extracted from Camellia seeds was made into liquid with double distilled water (DDW) with the mass concentration of 1.0 $\mathrm{mg} / \mathrm{mL}$ and diluted into differently concentrated gradients $(25.0,20.0,15.0$, 10.0 and $5.0 \mu \mathrm{g} / \mathrm{mL}$ ). $1.0 \mathrm{~mL}$ of the above sample solutions was taken and poured into a test tube which was then added with $3.0 \mathrm{~mL}$ of DPPH liquid $(0.04 \mathrm{~g} / \mathrm{L})$. After mixing, a chart was drawn according to sample solutions' scavenging capacity to $\mathrm{DPPH} \cdot$, and ascorbic acid (Vc) was taken as a control and prepared with DDW before using (Guoet al.,2010, Acemogluet al.,2012). Three parallel samples were made and each parallel sample was tested three 
times. Clearance rate of $\mathrm{DPPH} \bullet$ was calculated according to the following formula:

$$
P=\left(1-A_{S} / A_{C}\right) \times 100(1-2)
$$

where $\mathrm{P}$ refers to clearance rate, AC refers to absorbance value of DPPH solution without sample adding, AS refers to absorbance values of the samples.

(2) Ability to scavenge hydroxyl radicals

Ability of samples to scavenge hydroxyl radicals was determined referring to methods mentioned in literatures (Wang et al.,2009, Li et al.,2015), $1 \mathrm{~mL}$ of absolute ethyl alcohol containing $0.75 \mathrm{mmol} / \mathrm{L}$ phenanthroline, $2 \mathrm{~mL}$ of $\mathrm{PBS}$ $(0.15 \mathrm{mmol} / \mathrm{L}, \mathrm{pH}: 7.4)$ and $1 \mathrm{~mL}$ of differently concentrated samples were mixed, and then $1 \mathrm{~mL}$ of ferrous sulfate liquid was added $(0.75 \mathrm{mmol} / \mathrm{L})$ as well as $1 \mathrm{~mL}$ of $\mathrm{H} 2 \mathrm{O} 2$ solution with the volume fraction of $0.01 \%$ was added. It was kept warm for an hour in a water bath $\left(37^{\circ} \mathrm{C}\right)$ and its absorbance value Bs was then measured at the wavelength of $536 \mathrm{~nm}$ and distilled water was taken as the control. Clearance rate of glycoprotein extracted from Camellia seeds to hydroxyl radicals was calculated based on the following formula:

$$
W=\left(B_{S}-B_{C}\right) /\left(B_{B}-B_{C}\right) \times 100(1-3)
$$

(3) Determination of reducing capacity

Reducing capacity was determined referring to methods mentioned in literatures (Sreejithet al., 2013, Al-Olayanet al.,2014). Differently concentrated samples $(2 \mathrm{~mL})$ were added with $2 \mathrm{~mL}$ of PBS $(0.2 \mathrm{~mol} / \mathrm{L}, \mathrm{pH}$ : 6.6) and $2 \mathrm{~mL}$ of potassium ferricyanide solution with the mass fraction of $1 \%$. After mixing, it was kept warm for $20 \mathrm{~min}$ in a water bath $\left(50^{\circ} \mathrm{C}\right)$ and then added with $2 \mathrm{~mL}$ of TDA liquid with the mass fraction of $10 \%$ and mixed. It was then centrifuged at $3000 \mathrm{r} / \mathrm{min}$ for $5 \mathrm{~min}$ and $2 \mathrm{~mL}$ of supernatant liquor was taken out. $2 \mathrm{~mL}$ of distilled water and $0.4 \mathrm{~mL}$ of ferric trichloride solution with the mass fraction of $0.1 \%$ were added and mixed and kept warm for $10 \mathrm{~min}$ in a water bath $\left(50{ }^{\circ} \mathrm{C}\right)$. Its absorbance value was measured at the wavelength of $700 \mathrm{~nm}$ when the solution changed from yellow to blue. Distilled water was taken as the control.

(4) Ability to scavenge superoxide anion free radicals

Ability of samples to scavenge superoxide anion free radicals was determined referring to methods mentioned in literatures (Kido et al.,2013, Jiang et al.,2014). Differently concentrated samples $(0.1 \mathrm{~mL})$ were added with $2.8 \mathrm{~mL}$ 
of Tris buffer $(0.1 \mathrm{~mol} / \mathrm{L}, \mathrm{pH}: 8.2)$. After mixing, it was kept warm for 10 min in a water bath $\left(25^{\circ} \mathrm{C}\right)$ and then added with $0.1 \mathrm{~mL}$ of pyrogallic acid liquid ( $3 \mathrm{mmol} / \mathrm{L})$ and mixed quickly. Its absorbance value was measured at the wavelength of $325 \mathrm{~nm}$ and A325 was read every $30 \mathrm{~s}$ and it ended $5 \mathrm{~min}$ later. The regression equation of the absorbance changing over time was made and auto-oxidation rate of pyrogallic acid was considered as the slope. Taking distilled water as the control, the slope was measured to be Vc and the inhibition ratio of glycoprotein to superoxide anion free radicals was figured out according to the following formula:

$$
K=\left(V_{C}-V_{S}\right) / V_{C} \times 100(1-4)
$$

\section{Determination of COGP2a specific rotation}

Glycoprotein COGP2a in Camellia seeds was accurately weighted and made into $5 \mathrm{mg} / \mathrm{mL}$ of aqueous solution. Taking distilled water as the control, its absorbance was measured with a rotation meter and the specific rotation was calculated based on the following formula. Wherein, $t$ refers to temperature, $\delta$ refers to the measured optical rotation, $C$ refers to concentration of the solution $(\mathrm{g} / \mathrm{mL})$ and $\mathrm{L}$ refers to length of sample tube $(\mathrm{dm})$.

\section{Calculation of $F$ value and $p$ value}

$$
[\alpha]_{h}^{t}=\frac{\partial}{L C}(1-5)
$$

$\mathrm{F}=\mathrm{MSR} / \mathrm{MSE}(\mathrm{MSR}$ (mean square regression) $=$ SSR (sum of square of regression)/degree of freedom, mean square error $(\mathrm{MSE})=\mathrm{SST}$ (sum of squares for total)/degree of freedom); generally, difference is considered as significant if $F$ value is larger than $F$ value with respect togiven $\alpha$; value refers to the probability of $\mathrm{F}, \mathrm{T}$ or other inspection amount larger than desired value; generally difference was considered as significant if $\mathrm{p}$ value is smaller than given $\alpha . \quad \mathrm{p}=\mathrm{P}(|\mathrm{U}|>=|\mathrm{u}|)=|\mathrm{u} \alpha / 2|)=\alpha$. $\mathrm{r}$ value refers to index of goodness of fitting which is used for evaluating the fitting goodness of model; the value is between -1 and 1 ; the more the value approaches 1 or -1 , the better the fitting is. $\mathrm{R}^{2}=\mathrm{SSR} / \mathrm{SST}$.

\section{Statistical processing}

SPSS 17.0 was applied to statistically analyze data and the data were expressed as mean \pm standard deviation (SD). Various components were compared using one-way ANOVA and the difference was considered to be statistically significant if $\mathrm{p}<0.05$. 


\section{EXPERIMENTAL RESULTS}

\section{Response surface optimization water extraction test results}

(1) Construction andanalysisof regression model based on water extraction method

Water extraction optimization test was performed as planned and results are shown in Table 1. Design expert 7.0.0 software was used to regress and fit protein and sugar yields, thereby obtaining a regression equation. Regression coding equations of protein and sugar yields are:

$Y_{1}=6.47+0.51 X_{1}+1.48 X_{2}+0.13 X_{3}+0.28 X_{1} X_{3}+0.063 X_{2} X_{3}-0.34 X_{1}^{2}-0.087 X_{2}^{2}+0.22 X_{3}^{2}$ an

d

$Y_{2}=13.52+0.84 X_{1}+1.98 X_{2}+0.22 X_{3}+0.017 X_{1} X_{2}+0.14 X_{1} X_{3}+0.055 X_{2} X_{3}-0.55 X_{1}^{2}+0.29 X_{2}^{2}-0.13 X_{3}^{2}$

respectively.

Table 1. Test design and results of crude glycoprotein extracted by response surface optimization water extraction

\begin{tabular}{|c|c|c|c|c|c|}
\hline No. & $\begin{array}{c}\text { Extraction } \\
\text { time } \mathrm{X}_{1}(\mathrm{~h})\end{array}$ & $\begin{array}{c}\text { Temperature } \\
\mathrm{X}_{2}\left({ }^{\circ} \mathrm{C}\right)\end{array}$ & $\begin{array}{c}\text { Liquid-to-solid } \\
\text { ratio } \mathrm{X}_{3}(\mathrm{~mL} / \mathrm{g})\end{array}$ & $\begin{array}{c}\text { Protein } \\
\text { yield }(\%)\end{array}$ & $\begin{array}{c}\text { Sugar } \\
\text { yield }(\%)\end{array}$ \\
\hline $\mathrm{Y}_{1}$ & 3 & 60 & 15 & 8.25 & 16.24 \\
\hline $\mathrm{Y}_{2}$ & 2 & 50 & 15 & 6.54 & 13.55 \\
\hline $\mathrm{Y}_{3}$ & 2 & 50 & 15 & 6.41 & 13.48 \\
\hline $\mathrm{Y}_{4}$ & 2 & 60 & 10 & 7.95 & 15.31 \\
\hline $\mathrm{Y}_{5}$ & 3 & 50 & 20 & 7.33 & 13.96 \\
\hline $\mathrm{Y}_{6}$ & 1 & 60 & 15 & 7.05 & 14.45 \\
\hline $\mathrm{Y}_{7}$ & 1 & 50 & 15 & 5.95 & 12.09 \\
\hline $\mathrm{Y}_{8}$ & 2 & 40 & 10 & 5.35 & 11.55 \\
\hline $\mathrm{Y}_{9}$ & 2 & 50 & 15 & 6.26 & 13.39 \\
\hline $\mathrm{Y}_{10}$ & 2 & 50 & 15 & 6.95 & 13.85 \\
\hline $\mathrm{Y}_{11}$ & 1 & 50 & 10 & 5.90 & 12.02 \\
\hline $\mathrm{Y}_{12}$ & 3 & 50 & 10 & 6.17 & 13.36 \\
\hline $\mathrm{Y}_{13}$ & 2 & 50 & 15 & 6.25 & 13.45 \\
\hline $\mathrm{Y}_{14}$ & 2 & 60 & 20 & 8.05 & 15.92 \\
\hline $\mathrm{Y}_{15}$ & 1 & 40 & 15 & 3.88 & 10.38 \\
\hline $\mathrm{Y}_{16}$ & 3 & 40 & 15 & 5.10 & 12.03 \\
\hline $\mathrm{Y}_{17}$ & 2 & 40 & 20 & 5.15 & 11.95 \\
\hline & & & & & \\
\hline
\end{tabular}

Feng and Liu, Analysis on effect of separation and purification of glycoprotein $\quad 122$ extracted from Camellia seeds and its functional activity as basis for the economic development of Camellia oleifera industry 
Data obtained from water extraction test were processed with analysis of variance and significance test (Table 2). It could be seen that the influence of three influence factors on the sugar yield reached an extremely significant level while only the influences of extraction time and temperature on the protein yield were extremely significant, and the influence of interaction term failed to reach a significant level.

Table 2. Variance analysis on protein and sugar yields

\begin{tabular}{|c|c|c|c|c|c|c|c|c|c|}
\hline \multirow{2}{*}{$\begin{array}{l}\text { Source of } \\
\text { variation }\end{array}$} & \multicolumn{2}{|c|}{ Sum of squares } & \multirow{2}{*}{$\begin{array}{l}\text { Degree } \\
\text { of } \\
\text { freedom }\end{array}$} & \multicolumn{2}{|c|}{ Mean square } & \multicolumn{2}{|l|}{$\mathrm{F}$} & \multicolumn{2}{|c|}{2} \\
\hline & $\begin{array}{c}\text { Protein } \\
\text { yield }\end{array}$ & $\begin{array}{l}\text { Sugar } \\
\text { yield }\end{array}$ & & $\begin{array}{l}\text { Protei } \\
\mathrm{n} \text { yield }\end{array}$ & $\begin{array}{r}\text { Sugar } \\
\text { yield }\end{array}$ & $\begin{array}{c}\text { Protein } \\
\text { yield }\end{array}$ & $\begin{array}{l}\text { Sugar } \\
\text { yield }\end{array}$ & $\begin{array}{c}\text { Protein } \\
\text { yield }\end{array}$ & $\begin{array}{c}\text { Sugar } \\
\text { yield }\end{array}$ \\
\hline $\begin{array}{c}\text { Regression } \\
\text { model }\end{array}$ & 20.85 & 39.20 & 9 & 2.33 & 4.33 & 23.85 & 154.91 & 0.0002 & $\begin{array}{c}<0.00 \\
01\end{array}$ \\
\hline $\mathrm{X}_{1}$ & 2.13 & 5.71 & 1 & 2.10 & 5.71 & 21.75 & 202.58 & 0.0022 & $\begin{array}{c}<0.00 \\
01\end{array}$ \\
\hline $\mathrm{X}_{2}$ & 17.58 & 31.02 & 1 & 17.56 & 31.02 & 180.78 & $\begin{array}{c}1116.9 \\
5\end{array}$ & $\begin{array}{c}<0.000 \\
1\end{array}$ & $\begin{array}{c}<0.00 \\
01\end{array}$ \\
\hline$X_{3}$ & 0.15 & 0.36 & 1 & 0.15 & 0.36 & 1.46 & 13.16 & 0.2683 & 0.0085 \\
\hline $\mathrm{X}_{1} \mathrm{X}_{2}$ & 0.00 & $\begin{array}{l}1.225 \\
\text { E-003 }\end{array}$ & 1 & $0 . \overline{00}$ & $\begin{array}{l}1.225 \\
\text { E-003 }\end{array}$ & 0.00 & 0.045 & 1.0000 & 0.8405 \\
\hline$X_{1} X_{3}$ & 0.33 & 0.079 & 1 & 0.32 & 0.079 & 3.18 & 2.82 & 0.1182 & 0.1387 \\
\hline$X_{2} X_{3}$ & 0.015 & 0.013 & 1 & 0.018 & 0.013 & 0.18 & 0.45 & 0.7005 & 0.5326 \\
\hline$X_{1}^{2}$ & 050 & 1.25 & 1 & 0.50 & 1.25 & 5.08 & 44.86 & 0.0592 & 0.0004 \\
\hline$X_{2}^{2}$ & 0.033 & 0.33 & 1 & 0.033 & 0.33 & 0.34 & 12.38 & 0.5848 & 0.0098 \\
\hline & 0 & 0.072 & 1 & 0.22 & 0.072 & 2.13 & 2.51 & 0.1899 & 0.1565 \\
\hline $\begin{array}{c}\text { Residual } \\
\text { error }\end{array}$ & 0.66 & 0.21 & 7 & 0.098 & 0.027 & & & & \\
\hline
\end{tabular}

$P$ values of the two regression equations were 0.0002 and $<0.0001$ respectively, which suggested that the relationship between the regression equations and all the independent variables was highly significant. However, $\mathrm{p}$ values of lack of fit of the two equations were 0.3135 and 0.6347 respectively (>0.05), indicating that there was no obvious difference and 
other factors had little influence on test results. Residual error was caused by random errors and the model could well reflect data. In the meantime, the two regression equations' multiple correlation coefficients R2 were 0.9278 and 0.9886 respectively, which fitted well with actual situations. Therefore, the regression equation could be used to analyze and predict glycoprotein extraction process.

\section{In vitroantitumor activity of crude glycoprotein extracted from Camellia seeds}

MTT test was performed to investigate in vitroantitumor activity of differently concentrated crude glycoprotein and its inhibiting effect on human hepatoma cell HepG2, gastric cancer cell MGC-803 and breast cancer cell MCF-7 is displayed in Table 3.

Table 3 Inhibiting effect of crude glycoprotein extracted from Camellia seeds on different tumor cells

\begin{tabular}{|c|c|c|c|c|}
\hline Groups & $\begin{array}{c}\text { Concentration } \\
(\mu \mathrm{g} / \mathrm{mL})\end{array}$ & $\begin{array}{c}\text { HepG2 } \\
\text { inhibition ratio } \\
(\%)\end{array}$ & $\begin{array}{c}\text { MGC-803 } \\
\text { inhibition } \\
\text { ratio }(\%) \\
\end{array}$ & $\begin{array}{c}\text { MCF-7 } \\
\text { inhibition } \\
\text { ratio }(\%) \\
\end{array}$ \\
\hline $\begin{array}{l}\text { Negative control } \\
\text { group }\end{array}$ & & & - & - \\
\hline $\begin{array}{l}\text { Positive control } \\
\text { group(paclitaxel) }\end{array}$ & & 1.03 & $75.27 \pm 2.36$ & $91.55 \pm 0.58$ \\
\hline \multirow{5}{*}{$\begin{array}{c}\text { Crude } \\
\text { glycoprotein } \\
\text { obtained by } \\
\text { buffer solution } \\
\text { method }\end{array}$} & 200 & $91.26 \pm 2.59$ & $49.85 \pm 1.39$ & $79.65 \pm 3.23$ \\
\hline & 50 & $70.05 \pm 3.19$ & $16.02 \pm 0.97$ & $45.29 \pm 1.58$ \\
\hline & 12.50 & $4.65 \pm 0.58$ & $10.73 \pm 0.65$ & $11.66 \pm 0.68$ \\
\hline & 3.12 & $2.38 \pm 0.29$ & $1.63 \pm 0.13$ & $3.86 \pm 0.11$ \\
\hline & 0.78 & $2.28 \pm 0.20$ & $0.58 \pm 0.09$ & $2.45 \pm 0.05$ \\
\hline \multirow{5}{*}{$\begin{array}{l}\text { Crude } \\
\text { glycoprotein } \\
\text { obtained by } \\
\text { water } \\
\text { extraction }\end{array}$} & 200 & $90.81 \pm 2.12$ & $51.98 \pm 3.33$ & $79.65 \pm 2.88$ \\
\hline & 50 & $63.21 \pm 1.56$ & $40.23 \pm 1.03$ & $51.28 \pm 1.09$ \\
\hline & 12.50 & $47.44 \pm 2.65$ & $19.22 \pm 0.86$ & $23.97 \pm 0.97$ \\
\hline & 3.12 & $25.55 \pm 1.03$ & $6.75 \pm 0.78$ & $5.45 \pm 1.23$ \\
\hline & 0.78 & $10.18 \pm 0.75$ & $1.34 \pm 0.10$ & $0.53 \pm 0.05$ \\
\hline
\end{tabular}

It could be seen that crude glycoprotein obtained by buffer solution method and water extraction has a certain inhibiting effect on those three tumor cells, and a strong stronger in vitro antitumor activity. 
Crude glycoprotein has the greatest inhibiting effect on human hepatoma cell HepG2 as it is sensitive to the crude glycoprotein obtained in the two ways. IC50 of crude glycoprotein obtained in the two ways to HepG2 cell was calculated to be 36.794 and $15.164 \mu \mathrm{g} / \mathrm{mL}$ respectively. IC50 could reflect sample's ability to induce apoptosis of tumor cells and lower IC50 showed stronger apoptosis ability. Hence, crude glycoprotein obtained by water extraction has better antitumor activity. Inhibiting effect of samples obtained by water extraction on HepG2 cell increases with concentration, showing an obvious dose-effect relationship. The inhibition ratio reaches the maximum $(90.80 \%)$ at the highest concentration of $200 \mu \mathrm{g} / \mathrm{mL}$, which was close to paclitaxel's inhibition ratio in positive control group.

In the experiment above, sample glycoprotein had the greatest inhibiting effect on human hepatoma cell HepG2; so, HepG2 was selected for morphological observation. Figure 1 shows effect of crude glycoprotein on HepG2 tumor cell's morphology under differently concentrated conditions $(3.12,12.50,50,200 \mu \mathrm{g} / \mathrm{mL})$. It was observed that HepG2 tumor cell was complete and rich in number in the negative control group; sharply reduced number of HepG2 tumor cell, incomplete cells and obvious cell debris were found in the positive control group (paclitaxel) high concentration group (200 $\mu \mathrm{g} / \mathrm{mL}$ ), while other dose groups showed different numbers of cells with concentration; cell damage was also related to the concentration.

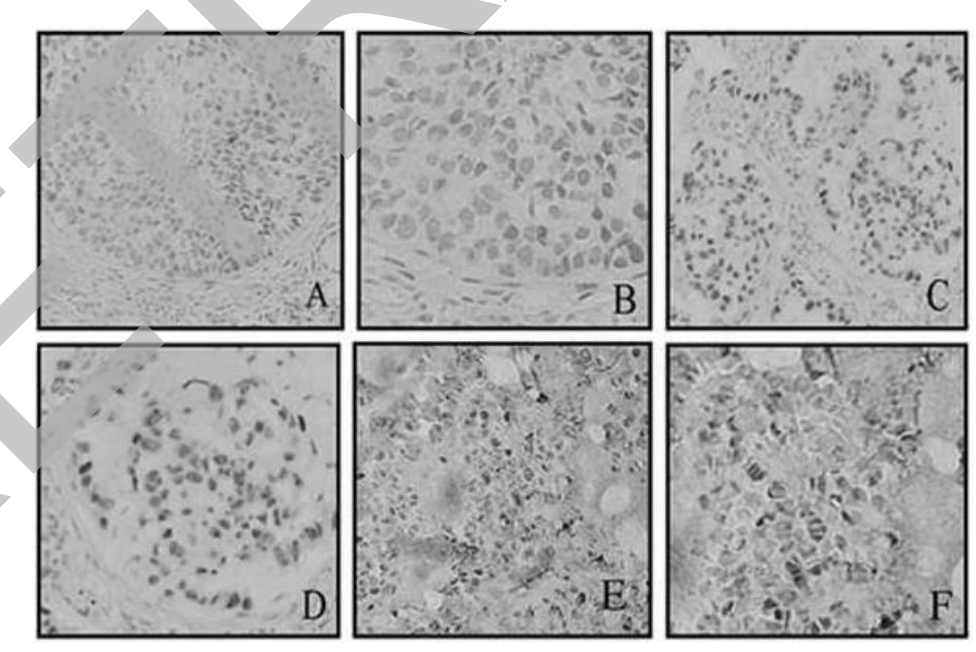

Figure 1. Inhibiting effect of crude glycoprotein extracted from Camellia seeds on

HepG2 tumor cell 
In vitroscavenging activity of crude glycoprotein extracted from Camellia seeds on DPPH, $\bullet \mathrm{OH}$ and $\mathrm{O}_{2}{ }^{\mathrm{g}-}$ free radicals and its total reducing power are shown in figure 2 .

A

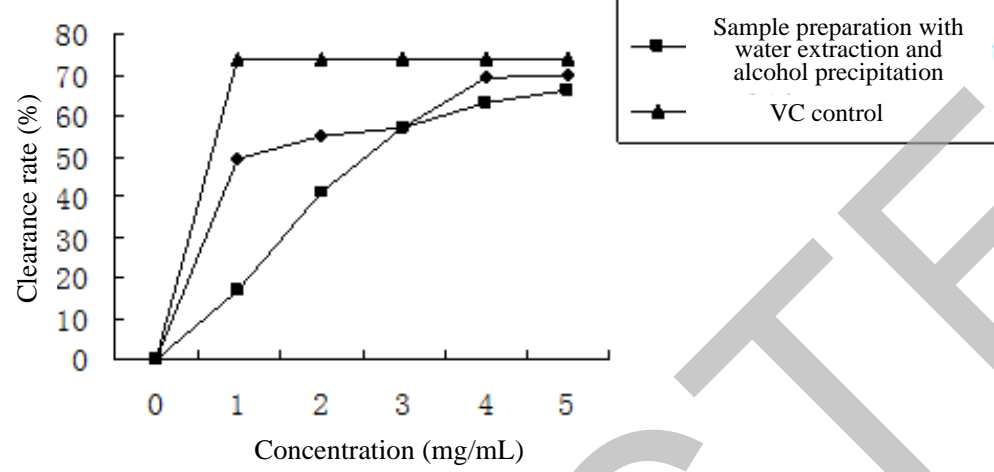

B
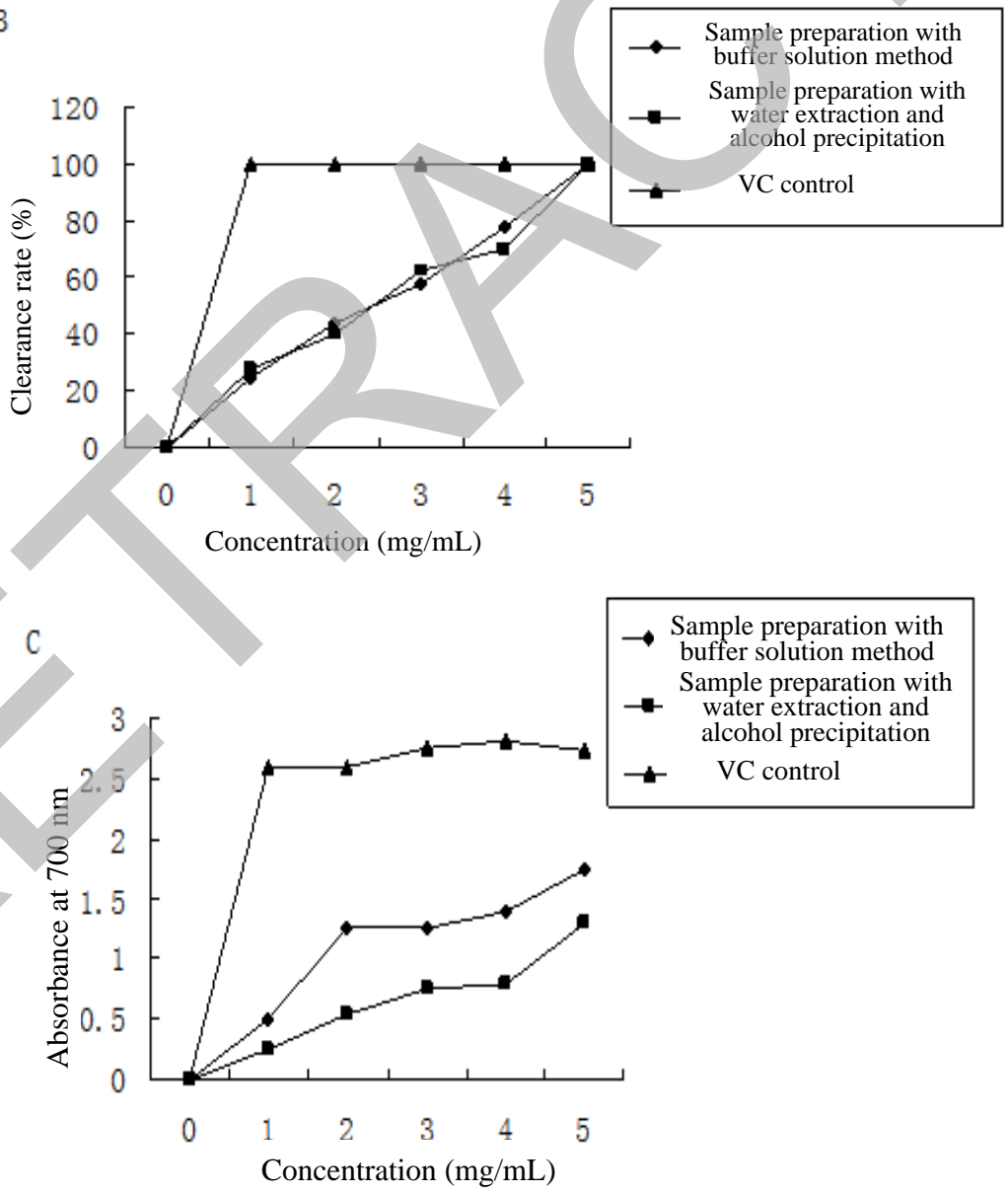

Feng and Liu, Analysis on effect of separation and purification of glycoprotein 


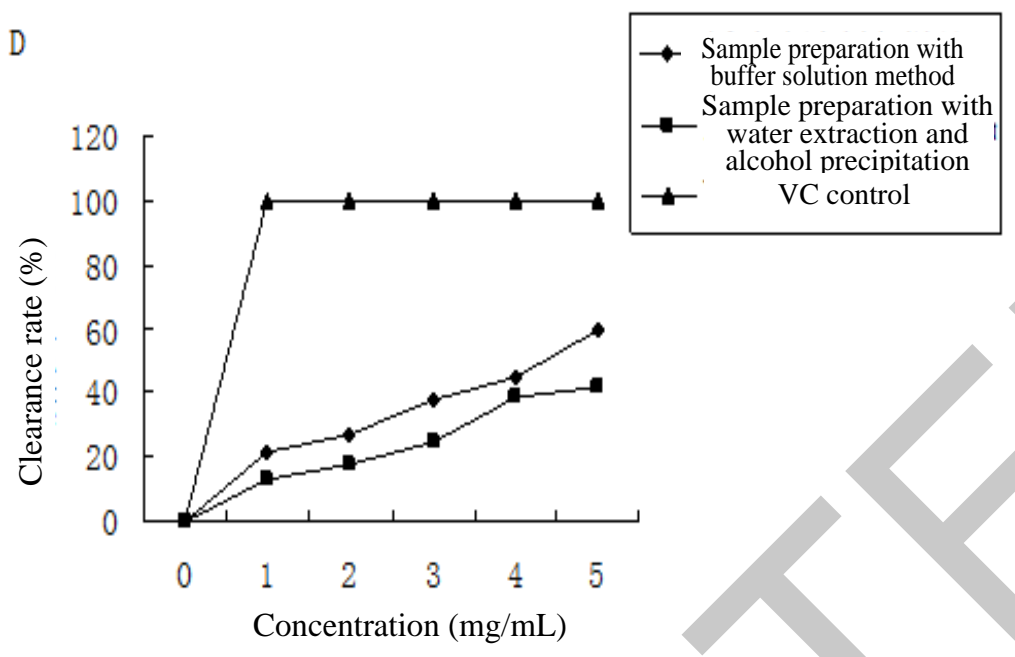

Figure 2:In vitro antioxidant effect of crude glycoprotein extracted from Camellia seeds. A: scavenging effect of crude glycoprotein extracted from Camellia seeds on DPPH: B: scavenging effect of crude glycoprotein extracted from Camellia seeds on hydroxyl radicals: C: total reducing power of crude glycoprotein extracted from Camellia seeds: D: scavenging effect of crude glycoprotein extracted from Camellia seeds on superoxide anion free radicals

Crude glycoprotein extracted from Camellia seeds in different ways had certain antioxidant ability and its scavenging activity on $\mathrm{DPPH}, \cdot \mathrm{OH}$ and $\mathrm{O}_{2}^{\mathrm{g}-}$ as well as total reducing power became more obvious with the concentration, showing a certain dose-effect relationship. 50\% effective concentration (EC50) was 2.060 and $2.051 \mathrm{mg} / \mathrm{mL}$ respectively for crude glycoprotein obtained by buffer solution method and water extraction scavenging $\cdot \mathrm{OH} ; 1.277$ and $2.771 \mathrm{mg} / \mathrm{mL}$ for scavenging DPPH. The differences of DPPH and $\bullet \mathrm{OH}$ clearance of crude glycoprotein extracted from Camellia seeds in the two ways were not significant when the concentration was $5.00 \mathrm{mg} / \mathrm{mL}$. However, there was a significant difference in $\mathrm{O}_{2}{ }^{\mathrm{g}-}$ free radicals scavenging and total reducing power of crude glycoprotein extracted in the two ways, and its EC50 was 4.430 and $7.282 \mathrm{mg} / \mathrm{mL}$ respectively. Antioxidant effect of glycoprotein samples extracted in the two ways increased with the increase of the concentration, but glycoprotein's effects on 
$\mathrm{O}_{2}{ }^{\mathrm{g}}$ - free radicals clearance and total reducing power were lower than that on positive control VC.

\section{Determination of specific rotation of glycoprotein COGP2a extracted from Camellia seeds}

Aqueous solution of glycoprotein COGP2a extracted from Camellia seeds was measured three times on a polarimeter and its average value was taken.

Specific rotation of COGP $2 \mathrm{a}[\alpha]_{n}^{20}$ was calculated to be -32.5

\section{DISCUSSION}

Key impact factors of Camellia seeds glycoprotein were extracted using buffer solution method and water extraction and a regression model was constructed, with a good fitting suggested by analysis of variance. MTT was used to investigate the in vitro antitumor activity of Camellia seeds glycoprotein.

Results showed that crude glycoprotein extracted from Camellia seeds had certain inhibiting effect on HepG2, MGC-803 and MCF-7, in which, its inhibiting effect on HepG2 cell was the greatest. Crude glycoprotein obtained by water extraction had a stronger antitumor effect. Microscopic observation suggested that, crude glycoprotein extracted from camellia seeds was found to have an obvious inhibiting effect on HepG2 cell; damaged integrity and obvious cell debris were observed on HepG2 cell and the damage extent of cell was positively related to sample concentration. This study suggested that Camellia seeds glycoprotein had obvious inhibitory effect on many cancer cells. The work is of important theoretical and practical significance to the improvement of utilization value of Camelliaresources, the enhancement of comprehensive development and utilization approach of high additional value of Camelliaand the enrichment of categories and functions of active glycoprotein.

\section{ACKNOWLEDGEMENT}

Project: Evaluation method of frozen storage on the quality characteristics of tilapia via fractal dimension (Natural science foundation of Hainan province, 20163043). 
Project: Based on the systematic reliable coupling mechanism of the marine industry and land-based industry in the south sea region and its evaluation studies (Natural science foundation of Hainan province, 20167245).

2015 Hainan Province Philosophy Social and Science Planning Project "The governance efficiency evaluation and the improvement research with the synergy of the land and the sea (item number: HNSK(JD)15-38).

Hainan University Youth Fund Project " The research about the government public service support system established in the Hainan Special Tourist Zone" (QNJJ1510).

\section{REFERENCES}

1. Acemoglu D, Robinson J A, 2012. The Colonial Origins of Comparative Development: An Empirical Investigation: Comment.American Economic Review, 102(6):3059-76.

2. Ajiboye T O, Iliasu G A, Adeleye A O, et al, 2014. Nutritional and antioxidant dispositions of sorghum/millet-based beverages indigenous to Nigeria. Food Science \& Nutrition, 2(5):597-604.

3. Al-Olayan E M, El-Khadragy M F, Metwally D M, et al, 2014. Protective effects of pomegranate (Punicagranatum) juice on testes against carbon tetrachloride intoxication in rats. BMC Complementary \& Alternative Medicine, 14(1):259-266.

4. Barik S, Bhuniya A, Banerjee $\mathrm{S}$, et al, 2013. Neem leaf glycoprotein is superior than Cisplatin and Sunitinib malate in restricting melanoma growth by normalization of tumormicroenvironment.InternationalImmunopharmacology, 17(1):42-49.

5. Dawson I K, Leakey R, Clement C R, et al, 2014. The management of tree genetic resources and the livelihoods of rural communities in the tropics: Non-timber forest products, smallholder agroforestry practices and tree commodity crops. Forest Ecology \& Management, 333(1):9-21.

Dos Santos M T, Gerbaud V, Roux G A C L, 2014.Beyond biofuels: economic opportunities, recent advances and challenges in property modeling for vegetable oils. Green Processing \& Synthesis, 3(6):401-410.

7. Fraga M, Bruxel F, Lagranha V L, et al, 2011. Influence of phospholipid composition on cationic emulsions/DNA complexes: physicochemical properties, cytotoxicity, and transfection on Hep G2 cells. International Journal of Nanomedicine, 6(1): 2213-2220. 
8. Gavrovic-Jankulovic M, Poulsen K, Brckalo T, et al, 2008. A novel recombinantly produced banana lectin isoform is a valuable tool for glycoproteomics and a potent modulator of the proliferation response in CD3+, CD4+, and CD8+ populations of human PBMCs.International Journal of Biochemistry \& Cell Biology, 40(5):929-41.

9. Guo J Y, Tan X F, Wang W H, et al, 2010. Isolation and cloning of full-length cDNA of FatB genes from Camellia oleiferaand its sequence analysis. Journal of Central South University of Forestry \& Technology, 30(9):66-75.

10. Guo Q H, Yang H J, Wang S D, 2015. Olanzapine inhibits the proliferation and induces the differentiation of glioma stem-like cells through modulating the Wnt signaling pathway in vitro.European Review for Medical \& Pharmacological Sciences, 19(13):2406-2415.

11. Islam S, Nasrin S, Khan M A, et al, 2013. Evaluation of antioxidant and anticancer properties of the seed extracts of SyzygiumfruticosumRoxb. growing in Rajshahi, Bangladesh. BMC Complementary \& Alternative Medicine, 13(4):347-362.

12. Jiang J, Yuan X, Wang T, et al, 2014. Antioxidative and Cardioprotective Effects of Total Flavonoids Extracted from Dracocephalummoldavica L. Against Acute Ischemia/Reperfusion-Induced Myocardial Injury in Isolated Rat Heart.Cardiovascular Toxicology, 14(1):74-82.

13. Jin L, Lim K T, 2011. Inhibitory effect of plant-originated glycoprotein (27 $\mathrm{kDa}$ ) on expression of matrix metalloproteinase-9 in cadmium chloride-induced BNL CL.2 cells.Journal of Trace Elements in Medicine \& Biology, 25(25):239-46.

14. Kang S, Song B, Jian W, et al, 2013. Design, synthesis and insecticidal activities of novel acetamido derivatives containing N-pyridylpyrazolecarboxamides.European Journal of Medicinal Chemistry, 67(17):14-18.

15. Kido E A, Neto J R F, Silva R L, et al, 2013. Expression dynamics and genome distribution of osmoprotectants in soybean: identifying important components to face abiotic stress.BMC Bioinformatics, 14(1):352-353.

16. Kreul S M, Havighurst T, Kim K M, et al, 2012. A phase III skin cancer chemoprevention study of DFMO: long-term follow-up of skin cancer events and toxicity. Cancer Prevention Research, 5(12):1368-1374.

17. Li C, Fu X, Huang Q, et al, 2015. Ultrasonic extraction and structural identification of polysaccharides from Prunella vulgaris and its antioxidant and 
antiproliferative activities. European Food Research \& Technology, 240(1):49-60.

18. Lim JY, Hwang BY, Hwang KW, et al, 2012. Methylalpinumisoflavone inhibits lipopolysaccharide-induced inflammation in microglial cells by the NF-kappaB and MAPK signaling pathway.Phytotherapy Research Ptr, 26(12):1948-1956.

19. Metwaly M S, Dkhil M A, Al-Quraishy S, 2013. Anti-coccidial and anti-apoptotic activities of palm pollen grains on Eimeriapapillata -induced infection in mice. Biologia, 69(2):254-259.

20. Šebrlová, Kristýna, Peš O, Slaninová I, et al, 2015. Seasonal variation in alkaloid composition and antiproliferative activity of Stylophorum lasiocarpum (Oliv.) Fedde. Chemical Papers, 69(5):698-708.

21. Sousa T N, Tarazona-Santos E M, Wilson D J, et al, 2010. Genetic variability and natural selection at the ligand domain of the Duffy binding protein in Brazilian Plasmodium vivax populations.Malaria Journal, 9(1):1-12.

22. Sreejith M, Kannappan N, Santhiagu A, et al, 2013. In vitro xanthine oxidase inhibitory and antioxidant activities of aerial parts of FlacourtiasepiariaRoxb.Oriental Pharmacy \& Experimental Medicine, 13(2):113-120.

23. Steiner J P, Bachani M, Wolfson-Stofko B, et al, 2014. Interaction of Paroxetine with Mitochondrial Proteins Mediates Neuroprotection. Journal of the American Society for Experimental Neurotherapeutics, 12(1):1-17.

24. Thomas A T, Rao J V, Subrahmanyam V M, et al, 2011. In vitro anticancer activity of microbial isolates from diverse habitats. Braz J Pharm Sci, 47(2):279-287.

25. Wang A N, Yi X W, Yu H F, et al, 2009. Free radical scavenging activity of Lactobacillus fermentumin vitro and its antioxidative effect on growing-finishing pigs.Journal of Applied Microbiology, 107(4):1140-1148.

26. Wu P, Ma X, Tigabu M, et al, 2011. Root morphological plasticity and biomass production of two Chinese fir clones with high phosphorus efficiency under low phosphorus stress.Canadian Journal of Forest Research, 41(2):228-234(7).

27. Xiu-Zhen Z, Ling W, Dong-Wu L, et al, 2014. Synergistic inhibitory effect of berberine and d-limonene on human gastric carcinoma cell line MGC803. Journal of Medicinal Food, 17(9):955-962.

28. Zhang Y, Trinh K T L, Yoo I S, et al, 2014. One-step glass-like coating of polycarbonate for seamless DNA purification and amplification on an 
integrated monolithic microdevice. Sensors \& Actuators B Chemical, 202(4):1281-1289.

29. Zhao H T, Wang Z Y, Ma F M, Yang X, Cheng C L, Yao L, 2012. Protective Effect of Anthocyanin from LoniceraCaerulea var. Edulis on Radiation-Induced Damage in Mice.International Journal of Molecular Sciences, 13(9):11773-11782.

30. Zhao J, Liu T, Ma L, et al, 2011. Antioxidant and preventive effects of extract from nymphaea Candida flower on in vitro immunological liver injury of rat primary hepatocyte cultures.Evidence-based Complementary and Alternative Medicine, 39(2011):1-8. 